\title{
Study on buying pattern and buying behaviour of hybrid castor growing farmers in Aravalli district of Gujarat state
}

\section{Muddasir Ahmad, Gautam Parmar and Alpesh Leua}

Received : 29.12.2017; Revised : 06.03.2018; Accepted : 20.03.2018

\begin{abstract}
The castor is an important cash crop for the India, the Gujarat is one of the leading state in castor production. The present study aims to study the buying pattern and buying behaviour of hybrid castor seeds by farmers. The study was undertaken in the five villages of Aravalli district in Gujarat. The 100 hybrid castor growers were surveyed for data collection. The snowball sampling was used to get the responses. The simple descriptive statistics were used to analyse the data. From the study it was found that the acreage for castor cultivation is decreasing and farmers are shifting to more remunerative crops. The majority of respondents are having irrigation facility for castor. Majority of respondents have grown hybrid castor seeds in 4 to 6 acre. The 50 per cent farmers purchase $3-6 \mathrm{~kg}$ of castor seed while 40 per cent farmer purchase more than $6 \mathrm{~kg}$ of castor seeds last year. As far as buying behaviour of farmers is concerned, it was found that topmost factors to which farmers give preference while buying hybrid castor seed were yield potential, wilt resistance, brand image, timely availability and germination percentage of seed. More than eighty five per cent of farmers were using hybrid castor seed since more than five years, the effect of this on their buying behaviour was that they were buying hybrid castor seed mostly because of their own experience.
\end{abstract}

KEY WORDS : Buying behaviour for castor seeds, Buying pattern for castor seed, Hybrid castor seeds, Farmers behaviour

How to cite this paper : Ahmad, Muddasir, Parmar, Gautam and Leua, Alpesh (2018). Study on buying pattern and buying behaviour of hybrid castor growing farmers in Aravalli district of Gujarat state. Internat. J. Com. \& Bus. Manage, 11(1) : 38-43, DOI: 10.15740/HAS/ IJCBM/11.1/38-43.

\section{MEMBERS OF THE RESEARCH FORUM}

Correspondence to:

Muddasir Ahmad, ASPEE Agribusiness Management Institute, Navsari Agricultural University, Navsari (Gujarat) India

\section{Authors' affiliations:}

Gautam Parmar and Alpesh Leua, ASPEE Agribusiness Management Institute, Navsari Agricultural University, Navsari (Gujarat) India 